\title{
Charcot-Marie-Tooth disease type 1a (CMT1a): evidence for trisomy of the region p11.2 of chromosome 17 in south Wales families
}

\author{
John C MacMillan, M Upadhyaya, Peter S Harper
}

\begin{abstract}
The gene for Charcot-Marie-Tooth disease type 1a (CMT1a) has been localised to chromosome 17p11.2. Locus D17S122 is recognised by the DNA probe pVAW409R3 which detects an MspI polymorphism with three alleles in the normal population. Subjects with CMT1a show evidence of trisomy for this region of chromosome 17 by displaying either all three alleles or a dosage effect when only two alleles are present. This phenomenon was seen in 10 out of 11 families with type $I$ hereditary motor and sensory neuropathy (HMSN) where affected subjects were heterozygous for the MspI polymorphisms. This mutation is likely to have arisen from a non-reciprocal recombination event between non-sister chromatids of homologous chromosomes at meiosis I. The detection of this partial trisomy offers a rapid method for the diagnosis of CMT1a in families not suitable for linkage analysis.
\end{abstract}

The Charcot-Marie-Tooth syndrome is a heterogeneous group of disorders ${ }^{1}$ characterised by a clinical picture of distal muscle weakness and wasting, hypo- or areflexia, distal sensory loss, and often foot deformity. Genetic heterogeneity has been documented within the group classified as type I hereditary motor and sensory neuropathy (type I HMSN) ${ }^{2}$ with loci on chromosomes $1^{3}$ and $17 .{ }^{4}$ The chromosome 17 locus appears to be that most frequently linked to HMSN type I and this has been designated CMT1a. Raeymaekers et al have shown that all affected subjects in their family panel showed evidence of partial trisomy of region $17 \mathrm{p} 11.2$ as detected by probe pVAW409R3a (D17S122). The south Wales panel of Charcot-Marie-Tooth syndrome families have been ascertained as part of a population prevalence study of the major single gene neurological disorders in the region ${ }^{6}$ and represent an unselected group of families in which to assess the presence of the trisomy.

Institute of Medical Genetics, University of Wales College of Medicine, Heath Park, Cardiff CF4 4XN. J C MacMillan M Upadhyaya P S Harper

Correspondence to Dr MacMillan.

Received 20 June 1991. Revised version accepted 20 August 1991.
Materials and methods

Charcot-Marie-Tooth disease families were ascertained for a clinical and genetic linkage study. ${ }^{7}$ Clinical and, where necessary, electrophysiological examinations were carried out by one of us (JCM) and blood samples taken from all consenting adults. DNA was extracted from peripheral blood lymphocytes, digested with restriction enzyme $M s p I$, fractionated on $0.8 \%$ agarose gel, and transferred by Southern blotting to Hybond-N (Amersham). DNA probe was labelled with ${ }^{32} \mathrm{P}$ using primer extension. ${ }^{8}$ Membranes were prehybridised in $6 \times$ SSC $(1 \times \mathrm{SSC}=0.15 \mathrm{~mol} / 1 \mathrm{NaCl}, 0.015 \mathrm{~mol} / 1 \mathrm{Tris}$ sodium citrate), $5 \times$ Denhart's, $0.5 \%$ SDS (sodium dodecyl sulphate), and 7\% dextran sulphate for two hours. The labelled probe was added to the prehybridised membranes and hybridisation continued in the same solution for 18 hours at $65^{\circ} \mathrm{C}$. A posthybridisation wash was carried out at $65^{\circ} \mathrm{C}$ in $2 \times \mathrm{SSC}, 0.1 \%$ SDS. Membranes were then exposed to Fuji $x$ ray film at $-70^{\circ} \mathrm{C}$ with intensifying screens for one to five days. The repetitive sequences in the original pVAW409R3 probe were competed out with total genomic DNA $(0.5 \mu \mathrm{g} / \mu \mathrm{l})$ at $65^{\circ} \mathrm{C}$ for two hours.

DNA probe pVAW409R3 was provided by D Barker (Utah), via Dr C Van Broeckhoven (Antwerp) who also provided probe pVAW409R3a, a 1.4 kb EcoRI-BamHI single copy of probe pVAW409R3.5 Both probes detect alleles of sizes $2.8 \mathrm{~kb}, 2.7 \mathrm{~kb}$, and $1.9 \mathrm{~kb}$ after $M s p I$ digestion and have been mapped to region $17 \mathrm{p} 11 .^{9}$

\section{Results}

Subjects shown to be heterozygous for the pVAW409R3 MspI polymorphisms were screened for trisomy of region $17 \mathrm{p} 11.2$ using the probe pVAW409R3a. All affected, heterozygous, subjects in 10 out of 11 families with Charcot-Marie-Tooth disease with significantly slowed motor nerve conduction velocities (type I HMSN) showed evidence of the trisomy. This was manifest (figure) either as the presence of all three normal allelic bands in one subject (lane 1) or as a dosage effect of any

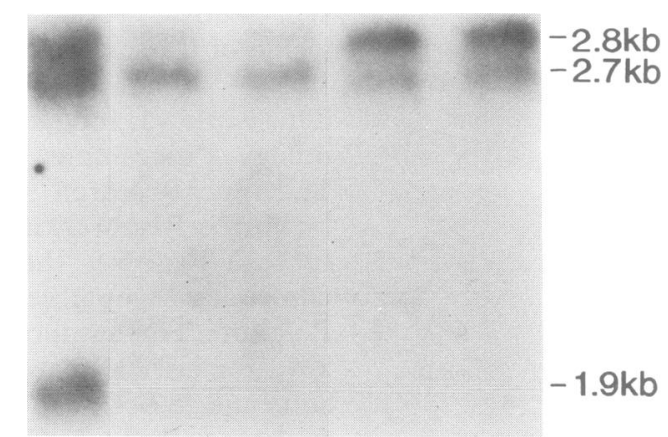

Bands detected using probe $p V A W 409 R 3 a$ of MspI digests. 
one of the allelic bands when only two were present (lanes 2, 3, 4, and 5).

\section{Discussion}

The DNA results indicate that in the majority of families (10 out of 11 in this study) with Charcot-Marie-Tooth disease with significantly slowed motor nerve conduction velocity (type I HMSN) the presence of trisomy for the locus D17S122, detected by probe pVAW409R3a, can be shown. It is unclear whether this is in itself the pathological mutation in CMTla or whether there is disruption of a gene at one of the breakpoints where the recombination event took place. The presence of all three alleles in an affected subject means that this phenomenon cannot have arisen as a duplication of a segment of chromosome $17 \mathrm{p} 11.2$ but is more likely to have arisen through a non-reciprocal recombination event between non-sister chromatids of homologous chromosomes at meiosis I.

The family where affected heterozygous subjects did not show the trisomy did not differ in the type or severity of their disease manifestations from the families where the trisomy was evident. In one family in the study population with type I HMSN, all affected subjects were homozygous for the MspI polymorphisms and were therefore not suitable for analysis by the methods outlined here. The patient base from which these families have been taken included several apparently isolated cases of type I HMSN. The assessment of these cases of chronic motor and sensory neuropathy using the trisomy as a marker for type I CMT can now be undertaken and this will have important implications in genetic counselling, as illustrated in family G of Raeymaekers et al. ${ }^{5}$ In those subjects/families homozygous for the MspI polymorphisms detected by pVAW409R3a, techniques such as pulsed field gel electrophoresis are likely to be useful in assessing the presence of the extra segment of DNA, and will define the size of the segment of interest.

We are grateful to Drs C Van Broeckhoven and $P$ Raeymaekers who made their findings known to us in advance of publication and provided the probes for this study. JCM is funded by the Welsh Office and Department of Health.

1 Bird TD. Hereditary motor-sensory neuropathies. Neurol Clin 1989;7:9-23.

2 Vance JM. Hereditary motor and sensory neuropathies. $\mathcal{f}$ Med Genet 1991;28:1-5.

3 Bird TD, Ott J, Giblett ER. Evidence for linkage of CharcotMarie-Tooth neuropathy to the Duffy locus on chromosome 1. Am $\mathcal{Y}$ Hum Genet 1982;34:388-94.

4 Vance JM, Nicholson GA, Yamaoka LH, et al. Linkage of Charcot-Marie-Tooth neuropathy type Ia to chromosome 17. Exp Neurol 1989;104:186-9.

5 Raeymaekers P, Timmerman V, Nelis E, et al. Duplication in Raeymaekers $\mathrm{P}$, Timmerman V, Nelis E, et al. Duplication in
chromosome $17 \mathrm{p} 11.2$ in Charcot-Marie-Tooth neuropathy type 1a (CMT 1a). Neuromuscular Disorders 1991;1:93-7.

6 MacMillan JC, Harper PS. Single gene neurological disorders in South Wales: an epidemiological study. Ann Neurol 1991;30:411-4.

7 MacMillan JC. The Charcot-Marie-Tooth syndrome in South Wales: a population genetic study. MD thesis, University of Aberdeen, 1991.

8 Feinberg AP, Vogelstein B. A technique for radiolabeling DNA restriction endonuclease fragments to high specific activity. Anal Biochem 1983;132:6-13.

9 Wright EC, Goldgar DE, Fain PR, Barker DF, Skolnick MH. A genetic map of human chromosome $17 \mathrm{p}$. Genomics 1990;7:103-9. 